\title{
Is ventilatory efficiency the next new thing in prehabilitation?
}

\author{
Sadeesh Srinathan, MD, MSc
}

\footnotetext{
From the Section of Thoracic Surgery, Department of Surgery, University of Manitoba, Winnipeg, Manitoba, Canada.

Disclosures: Author has nothing to disclose with regard to commercial support.

Received for publication April 13, 2019; accepted for publication April 15, 2019; available ahead of print June 12 , 2019.

Address for reprints: Sadeesh Srinathan, MD, MSc, Section of Thoracic Surgery, Room GE61, 820 Sherbrook St, Winnipeg, Manitoba R3A 1R9, Canada (E-mail: ssrinathan@exchange.hsc.mb.ca).

J Thorac Cardiovasc Surg 2020;159:e323-4

$0022-5223 / \$ 36.00$

Copyright (C) 2019 by The American Association for Thoracic Surgery

https://doi.org/10.1016/j.jtcvs.2019.04.054
}

The concept of "prehabilitation" is of increasing interest in surgery, and a reliable means of assessing the response to an exercise program is therefore useful. Cardiopulmonary exercise testing measures physical function to predict major outcomes after surgery. ${ }^{1}$ Peak oxygen consumption $\left(\mathrm{Vo}_{2 \text { peak }}\right)$ is a component measurement of cardiopulmonary exercise testing used to determine operability for lung cancer. $^{2,3}$

Ventilatory efficiency describes the relationship between minute ventilation ( $\mathrm{VE})$ and $\mathrm{CO}_{2}$ production $\left(\mathrm{VCO}_{2}\right)$, which is an additional measure obtained from cardiopulmonary exercise testing. If $\mathrm{VE}$ rises quickly relative to $\mathrm{VCO}_{2}$ production during exercise (to maintain the arterial $\mathrm{PaCO}_{2}$ ), then the $\mathrm{VE} / \mathrm{VCO}_{2}$ slope increases. An elevated slope $(>35)$ is an independent prognostic factor in lung resection, ${ }^{4}$ heart failure, ${ }^{5}$ and chronic obstructive pulmonary disease. ${ }^{6}$ In their article in this issue of the Journal, Gravier and colleagues ${ }^{7}$ determine whether $\mathrm{VE} / \mathrm{VCO}_{2}$ can be improved with an exercise program.

Gravier and colleagues ${ }^{7}$ report their findings on patients undergoing a prehabilitation program. They retrospectively reviewed high-risk patients in an exercise program to determine whether there was a change in $\mathrm{VE} / \mathrm{VCO}_{2}$ slope after the program and, if so, whether this change was related to $\mathrm{VO}_{2 \text { peak }}$

Gravier and colleagues ${ }^{7}$ found no change in the slope, but the $\mathrm{VO}_{2 \text { peak }}$ increased, and there was a moderate correlation between the change in $\mathrm{VE} / \mathrm{VCO}_{2}$ slope and change in the $\mathrm{VO}_{2 \text { peak }}$. They conclude that the slope did not change with the exercise program, even though other measures, such as $\mathrm{Vo}_{2 \text { peak }}$ and maximum power reached $\left(\mathrm{W}_{\text {peak }}\right)$, changed in the expected direction.

If ventilatory efficiency is an independent predictor of major outcomes in various disease states and reflects a separate biologic phenomenon not reflected by $\mathrm{VO}_{2 \text { peak }}$ or $\mathrm{W}_{\text {peak }}$, it could serve as a target for improvement with an exercise program or a target of further study to alter prognosis. Gravier and colleagues ${ }^{7}$ did as well as possible with the material intervention.

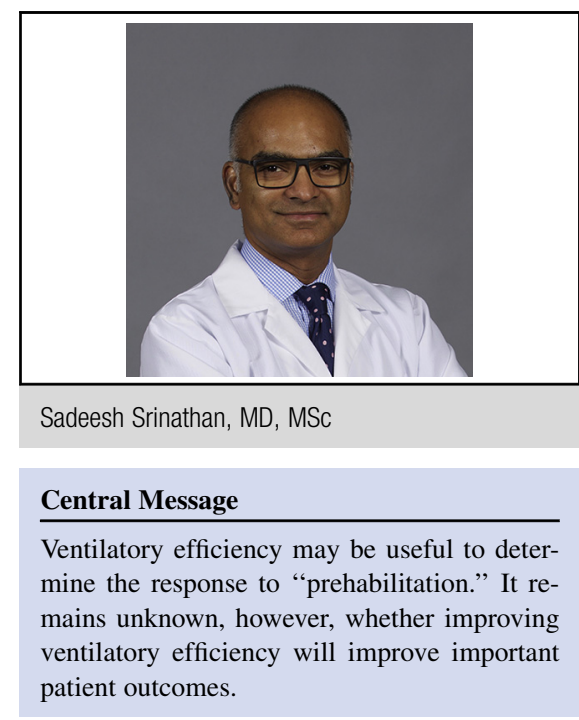

See Article page 2504 in the June 2019 issue.

available to them, but there are 2 issues that limit our confidence in their conclusions.

First, their study population was heterogeneous. The subjects included not only those with demonstrated limitation of pulmonary function $\left(\mathrm{VO}_{2 \text { peak }}<20 \mathrm{~mL} / \mathrm{kg} / \mathrm{min}\right.$ ) but also those thought to be at increased risk because of other comorbidities. Perhaps those with limitation in function could be expected to demonstrate improvement; however, it is not necessarily the case that the other risk group will respond similarly. Of the 50 subjects, $13(26 \%)$ were undergoing neoadjuvant therapy (NAC). This cohort both may start at a different functional baseline from the cohort without neoadjuvant therapy and may respond differently to the

Second, Gravier and colleagues ${ }^{7}$ concluded that there is no relationship between slope and exercise after comparing the medians of the slope. They did, however, find a significant correlation between changes in $\mathrm{VE} / \mathrm{VCO}_{2}$ slope and $\mathrm{VO}_{\text {2peak }}$. This correlation is a more sensitive analysis, because it uses all the data points available, rather than comparing medians (as they did in their other analyses showing no difference) and takes advantage of the variability in the data. According to this more sensitive analysis, the results of Gravier and colleagues ${ }^{7}$ could be interpreted to mean that there is indeed a change in the slope.

Ventilation efficiency may offer a new target for improvement in prehabilitation; however, a prospective study with a clearly characterized and homogeneous patient 
population with a consistently applied intervention will be required before any conclusions can be drawn about whether prehabilitation can increase ventilatory efficiency. More importantly, it remains to be seen whether improving ventilatory efficiency will result in improvement in important patient outcomes.

\section{References}

1. Wijeysundera DN, Pearse RM, Shulman MA, Abbott TEF, Torres E, Ambosta A, et al; METS Study Investigators. Assessment of functional capacity before major non-cardiac surgery: an international, prospective cohort study. Lancet. 2018;391: 2631-40.

2. Brunelli A, Kim AW, Berger KI, Addrizzo-Harris DJ. Physiologic evaluation of the patient with lung cancer being considered for resectional surgery. Chest. 2013;143(5 Suppl):e166S-90S.
3. Brunelli A, Charloux A, Bolliger CT, Rocco G, Sculier JP, Varela G, et al; European Respiratory Society and European Society of Thoracic Surgeons Joint Task Force on Fitness for Radical Therapy. ERS/ESTS clinical guidelines on fitness for radical therapy in lung cancer patients (surgery and chemo-radiotherapy). Eur Respir J. 2009;34:17-41.

4. Brunelli A, Belardinelli R, Pompili C, Xiumé F, Refai M, Salati M, et al. Minute ventilation-to-carbon dioxide output (VE/Vco2) slope is the strongest predictor of respiratory complications and death after pulmonary resection. Ann Thorac Surg. 2012;93:1802-6.

5. Kleber FX, Vietzke G, Wernecke KD, Bauer U, Opitz C, Wensel R, et al. Impairment of ventilatory efficiency in heart failure: prognostic impact. Circulation. 2000;101:2803-9.

6. Neder JA, Berton DC, Arbex FF, Alencar MC, Rocha A, Sperandio PA, et al. Physiological and clinical relevance of exercise ventilatory efficiency in COPD. Eur Respir J. 2017;49:1602036.

7. Gravier FE, Bonnevie T, Boujibar F, Médrinal C, Prieur G, Combret Y, et al. Effect of prehabilitation on ventilatory efficiency in non-small cell lung cancer patients: a cohort study. J Thorac Cardiovasc Surg. 2019;157:2504-12. 